\title{
The effect of ovarian reserve and receptor signalling on granulosa cell apoptosis during human follicle development
}

Article

Accepted Version

Creative Commons: Attribution-Noncommercial-No Derivative Works 4.0

Regan, S. L. P., Knight, P. G., Yovich, J. L., Stanger, J. D., Leung, Y., Arfuso, F., Almahbobi, G. and Dharmarajan, A. (2018) The effect of ovarian reserve and receptor signalling on granulosa cell apoptosis during human follicle development. Molecular and Cellular Endocrinology, 470. pp. 219-227. ISSN 0303-7207 doi: https://doi.org/10.1016/j.mce.2017.11.002 Available at https://centaur.reading.ac.uk/73739/

It is advisable to refer to the publisher's version if you intend to cite from the work. See Guidance on citing.

To link to this article DOI: http://dx.doi.org/10.1016/j.mce.2017.11.002

Publisher: Elsevier

All outputs in CentAUR are protected by Intellectual Property Rights law, including copyright law. Copyright and IPR is retained by the creators or other copyright holders. Terms and conditions for use of this material are defined in the End User Agreement. 


\section{CentAUR}

Central Archive at the University of Reading

Reading's research outputs online 


\section{Accepted Manuscript}

The effect of ovarian reserve and receptor signalling on granulosa cell apoptosis during human follicle development

Sheena L.P. Regan, Phil G. Knight, John L. Yovich, James D. Stanger, Yee Leung, Frank Arfuso, Ghanim Almahbobi, Arun Dharmarajan

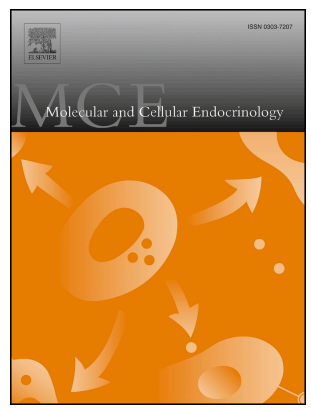

PII:

S0303-7207(17)30567-1

DOI:

10.1016/j.mce.2017.11.002

Reference: MCE 10116

To appear in: Molecular and Cellular Endocrinology

Received Date: 12 August 2017

Revised Date: 2 November 2017

Accepted Date: 3 November 2017

Please cite this article as: Regan, S.L.P., Knight, P.G., Yovich, J.L., Stanger, J.D., Leung, Y., Arfuso, F., Almahbobi, G., Dharmarajan, A., The effect of ovarian reserve and receptor signalling on granulosa cell apoptosis during human follicle development, Molecular and Cellular Endocrinology (2017), doi: 10.1016/j.mce.2017.11.002.

This is a PDF file of an unedited manuscript that has been accepted for publication. As a service to our customers we are providing this early version of the manuscript. The manuscript will undergo copyediting, typesetting, and review of the resulting proof before it is published in its final form. Please note that during the production process errors may be discovered which could affect the content, and all legal disclaimers that apply to the journal pertain. 
Human Granulosa Cell Apotosis

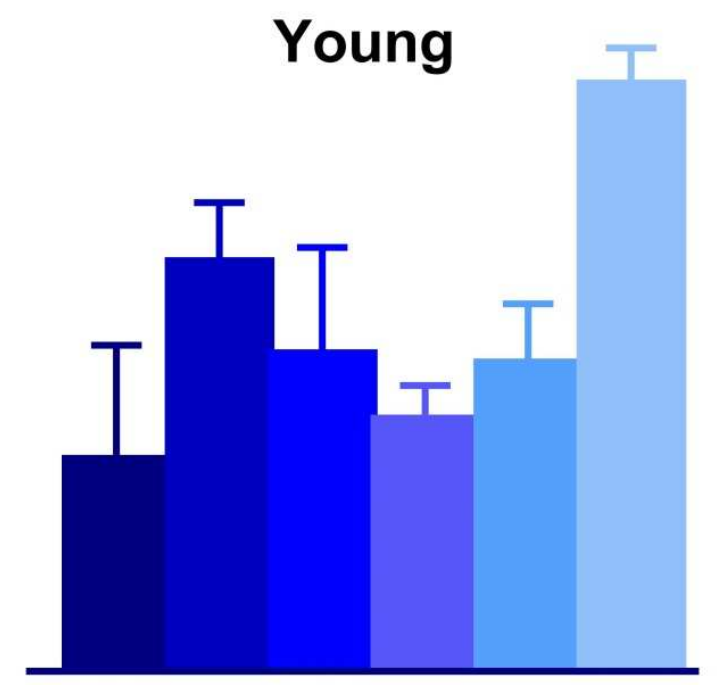

Older

Follicle size

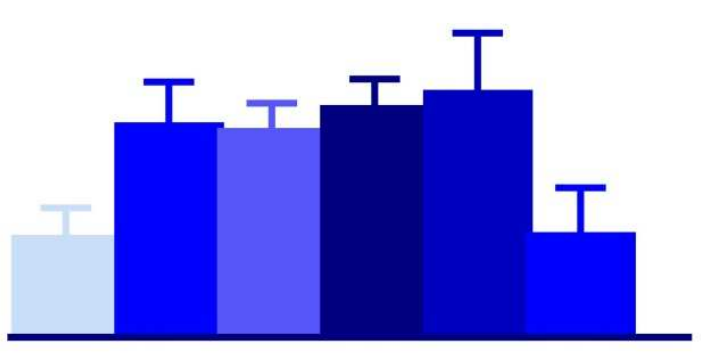


1 The effect of ovarian reserve and receptor signalling on granulosa

2 cell apoptosis during human follicle development

5 Sheena L.P. Regan ${ }^{a} *$, Phil G. Knight ${ }^{\mathrm{b}}$, John L.Yovich ${ }^{\mathrm{c}}$, James D. Stanger ${ }^{\mathrm{c}}$, Yee Leung ${ }^{\mathrm{d}}$, Frank Arfuso ${ }^{\mathrm{a}}$,

6 Ghanim Almahbobi ${ }^{\mathrm{e}}$, Arun Dharmarajan ${ }^{\mathrm{a}}$,

${ }^{\mathrm{a}}$ Stem Cell and Cancer Biology Laboratory, School of Biomedical Sciences, Curtin Health Innovation Research Institute, Curtin University, Perth, Australia. ${ }^{\mathrm{b}}$ School of Biological Sciences, Hopkins Building, University of Reading, Whiteknights, Reading RG6 6UB, UK. 'PIVET Medical Centre, Perth, Australia. ${ }^{\mathrm{E}}$ Western Australian Gynaecologic Cancer Service, King Edward Memorial Hospital for Women, Perth, Australia. ${ }^{\mathrm{S}}$ School of Biomedical Sciences, Curtin Health Innovation Research Institute, Curtin University, Perth, Australia.

${ }^{\mathrm{a}}$ Stem Cell and Cancer Biology Laboratory, School of Biomedical Sciences, Curtin Health Innovation Research Institute, Curtin University, Perth, Australia, GPO Box U1987, Perth, WA 6845, Australia 


\section{Introduction}

27 Ovulation rate is governed by the number of follicles growing in a stage-specific manner. The gonadotrophins follicle stimulating hormone (FSH) and luteinising hormone (LH) govern the growth rates of the follicles during cyclic folliculogenesis, and the receptor density influences the response of the follicles to gonadotrophin stimulation (Hsueh, Kawamura, Cheng et al., 2015). Recent evidence suggests that intraovarian growth factors, such as the bone morphogenetic proteins (BMPs), impact gonadotrophin receptor expression that ultimately controls the growth rate of the follicle (Al-Musawi, Gladwell and Knight, 2007,Di Pasquale, Beck-Peccoz and Persani, 2004).

Reproductive ageing is linked to the decline in capacity of follicular granulosa cells to express receptors, which causes an irreversible change to ovarian cellular dynamics, and ultimately reduces the capacity to reproduce (Cai, Lou, Dong et al., 2007,Nelson, Telfer and Anderson, 2013, Tilly J L, Billig H , Kowalski K I et al., 1992). Older patients typically have increased circulating FSH at the start of the cycle and reduced inhibin B, which gives rise to accelerated early follicle development. However, the growth rate slows towards the terminal stage of cyclic folliculogenesis, resulting in follicles that are smaller and with fewer granulosa cells (Santoro, Isaac, Neal-Perry et al., 2003 ,Seifer, Scott Jr, Bergh et al., 1999,Robertson, 2009,MacNaughton, Banah, McCloud et al., 1992,Vanden Brink, Robertson, Lim et al., 2015).

Apoptosis is a normal regulatory process that contributes to the maintenance of a healthy complement of follicles and their constituent oocytes (Yuan and Giudice, 1997). The granulosa cells are more susceptible to apoptosis in the follicle than the theca or cumulus cells (Bencomo, Pérez, Arteaga et al., 2006). High levels of granulosa cell death could impact follicle development and suppress oocyte growth (Sasson and Amsterdam, 2002,Irving-Rodgers, Krupa and Rodgers, 2003). In the late 1990s and early 2000 s, the levels of apoptosis in follicles were explored as potential markers of oocyte quality and to predict pregnancy outcome. However, its effectiveness as a marker was limited (Jančar, Kopitar, Ihan et 
al., 2007,Lee, Joo, Na et al., 2001,Nakahara, Saito, Saito et al., 1997, Oosterhuis, Michgelsen, Lambalk et al., 1998,Moffatt, Drury, Tomlinson et al., 2002). Further investigation then centred on indicators of oxidative stress that induce apoptosis and its impact on oocyte quality (Wiener-Megnazi, Vardi, Lissak et al., 2004). This was followed by research on adjunctive treatments to reduce apoptosis (Hyman, Margalioth, Rabinowitz et al., 2013).

The post-ovulatory fate of granulosa cells is to differentiate into granulosa-lutein cells in the corpus luteum. Alternatively, apoptosis may occur, which results in a systematic degradation of the DNA to low molecular weight fragments extruded from the cytoplasm, and isolated into atretic bodies or entirely engulfed by neighbouring granulosa cells (Van Wezel, Dharmarajan AM, Lavranos TC et al., 1999,van Wezel, Rodgers and Krupa, 1999). Another type of cell death termed necrosis results from a foreign insult to a cell, which subsequently ruptures and causes an inflammatory response. A third type of cell death is referred to as terminal differentiation of the antral granulosa cells, similar to the differentiation that occurs in skin epithelium The terminally differentiated granulosa cells become loosely associated to the granulosa membrana, and are eventually sloughed off into the antrum, similar to skin epithelial cells. The cells coalesce to form coagulated globules ranging in size from $40 \mu \mathrm{m}$ to $620 \mu \mathrm{m}$ (van Wezel et al., 1999,Hay, Cran and Moor, 1976). Alternatively, another form of programmed cell death called autophagy may occur, where the cell digests itself (Duerrschmidt, Zabirnyk, Nowicki et al., 2006,Vilser, Hueller, Nowicki et al., 2010).

Earlier studies on apoptosis of follicular cells have employed a range of analyses based on morphological assessment of pyknotic cell counts, TUNEL, and propidium iodide assessment, all with pooled follicle samples of unknown size (Yuan and Giudice, 1997,Nakahara et al., 1997,Oosterhuis et al., 1998,Seifer, 1996 ,Giampietro, Sancilio, Tiboni et al., 2006,Austin, Mihm, Evans et al., 2001,Bomsel-Helmreich, Gougeon, Thebault et al., 1979). Other studies have analysed activated caspase 3 levels, and compared these with TUNEL assay outcomes and with levels of various Bcl2 family 
members, reporting a wide range of apoptosis levels (D’haeseleer, Cocquyt, Cruchten et al., 2006,Albamonte, Albamonte, Stella et al., 2013).

Many of these studies suffer from technical limitations because they have relied on pooling follicles of different sizes, counting a small portion of the granulosa cells ( 100-1000), and have excluded follicles because of blood contamination, or failed to exclude white blood cells (Nakahara et al., 1997,Oosterhuis et al., 1998,Seifer, 1996 ). In addition, when propidium iodide and Annexin V-FITC are combined, spectral overlap was not compensated for, and made the incorrect interpretation of the quadrants as being apoptosis-induced necrotic cells (Jančar et al., 2007,Seifer, 1996 ,Giampietro et al., 2006).

From our previous experience, we determined that Annexin V stain, which indicates early onset of apoptosis, is unreliable because of unintentional damage caused by centrifuging cells at a high speed that induces early apoptosis (Regan, McFarlane, O'Shea et al., 2015).

Uniquely, the current study identifies granulosa cells based on positive FSH receptor expression, combined with excluding red and white blood cells. Therefore, the current study aims to further explore the changes in granulosal apoptosis of healthy follicles (not atretic); hence, indicating mitogenic growth/turnover rate rather than follicle death. By using optimized methodologies and experimental techniques, individual follicles ranging in size from $4 \mathrm{~mm}$ to $26 \mathrm{~mm}$ were analysed to determine the relationship between apoptosis $(7 \mathrm{AAD}+)$ as the ovarian follicle reserve is depleted with age.

\section{Methods}

A total of 198 follicles were collected from 31 patients undergoing standard in vitro fertilisation treatment (Table 1). Patients were aged between 23 and 45 years, with a range of infertility factors, but limited to exclude unusual medical conditions, endocrine dysfunction, polycystic ovarian syndrome and endometriosis, and were comprised of male factor, low ovarian reserve, donor sperm or unexplained 
fertility; and fertilisation was via intracytoplasmic sperm injection (ICSI). Patient treatment consisted of gonadotrophin releasing hormone antagonist suppression of LH (either Orgalutron or Cetrotide) in conjunction with commercially prepared recombinant (r) human FSH stimulation (either Puregon or

Gonal F), from cycle day 2 for $\sim 10$ days, as previously described (Regan, Knight, Yovich et al., 2016).

Ovulation was triggered with $10000 \mathrm{IU}$ HCG, and oocyte retrieval was 36 hours later by transvaginal oocyte aspiration (Regan et al., 2016). Body mass index (BMI) differences were not significant in this study.

Ovarian reserve was measured indirectly by the antral follicle count and was defined as the number of follicles between $2-10 \mathrm{~mm}$ in size that are present in total on $\sim$ day 2- 5 of a preliminary assessment cycle (Hansen, Hodnett, Knowlton et al., 2011). The patients were divided into groups based on the algorithm, as described previously (Regan et al., 2016), and a well-established clinical practice of patient treatment where IVF gonadotrophin treatment protocols are based on AFC as the main predictor and AMH as a minor modulator when the two measurements conflict (Yovich, Stanger and Hinchliffe, 2012). In the current study, the combined ovary follicle total corresponded to: Group $A+=30-39$ small follicles; group $\mathrm{A}=$ 20-29 small follicles; group B = 13-19 small follicles; group C = 9-12 small follicles; group $\mathrm{D}=5-8$ small follicles; and group $\mathrm{E}=\leq 4$ small follicles. Body mass index (BMI) differences amongst patient groups A-E were not significant in this study.

The diameter of the follicle was calculated using ultrasonography, as described previously (Regan et al., 2016). Each follicle was measured, punctured, and aspirated to remove only the follicular fluid; this would remove any contamination from other follicles or ovarian or vaginal epithelial cells (Quinn's Advantage with Hepes, Sage Media, Pasadena, California). This fluid is initially collected and checked for an oocyte. While the checking procedure by two embryologists takes place, the clinician flushes the follicle at $\sim 180$ psi to remove the loosely attached layers of antral granulosa cells until an oocyte is retrieved. When entering an adjacent follicle, a new collection tube is used, and will contain the new 
pure follicular fluid; again clearing contamination from other sources. Therefore, the collected follicle flush would only contain the antral granulosa cells that are easily removed during flushing. The cumulus ovarian complex was removed and the follicular flush was then layered onto a ficoll density gradient (555485; BD Biosciences, Perth, Australia) and centrifuged at $1500 \mathrm{rpm}$ (300g) for $30 \mathrm{~min}$ at room temp to isolate the granulosa cells and remove red blood cells (Regan et al., 2016).

\subsection{Immunolabelling of granulosa cells}

Aliquots of suspended granulosa cells $\left(1 \times 10^{6}\right.$ cells in $\left.100 \mu 1\right)$ were immunolabelled as previously described; analysed for receptor expression and apoptosis fresh on the same day (Regan et al., 2016,Regan, Knight, Yovich et al., 2017). Briefly, the cells were incubated with affinity purified goat polyclonal antibody to goat FSH receptor (sc-7798), and BMPR1B (sc-5679) (Santa Cruz

Biotechnology, Santa Cruz, CA, USA), and then incubated with a secondary antibody, donkey anti-goat conjugated to the fluorochrome Alexa 488 (Life Technologies Australia, Victoria, Australia) (Regan et al., 2016,Al-Samerria and Almahbobi, 2014 ). Unstained samples or the substitution of a primary antibody with pre-immune goat IgG (Millennium Science, Surrey Hills, Victoria Australia) at the same concentration as the primary antibody served as a negative control for auto-fluorescence. In the current study, the 'normal' goat IgG and unstained control cells emitted a similar average mean fluorescent intensity (MFI) and this was subtracted from the receptor measurement.

7-Amino-Actinomycin (7-AAD) is a membrane impermeant dye that is excluded from cells with an intact cell membrane. Granulosa cell membrane integrity breakdown allows 7-AAD to penetrate. It binds to double stranded DNA, excited at $488 \mathrm{~nm}$ wavelength, and emitting at a maximum $647 \mathrm{~nm}$ (Demchenko, 2013,Amsterdam, Sasson, Keren Tal et al., 2003). Briefly, cells were incubated with 7AAD (BD Biosciences, Perth, Australia) in the dark for $15 \mathrm{~min}$ at room temperature. A combination of unstained cells sample and 7-AAD positive cells from the same follicle, as per manufacturer's recommendation (Demchenko, 2013,Vermes, Haanen, Steffens-Nakken et al., 1995). 


\subsection{Flow cytometry}

Selective gating of the whole sample to identify a pure granulosa cell population was achieved by graphing forward scatter to remove doublets or globules 25-620 $\mu \mathrm{m}$ in size (FSC-H verses FSC-A), as previously described (Regan et al., 2016). The resulting population contained a granulosa cell population that revealed positive staining for the FSH receptor, which is unique to granulosa cells (Fig. 1) (Hermann and Heckert, 2007). Red blood cells were excluded using a Ficol gradient (555485; BD Biosciences, Perth, Australia), and white blood cells excluded since they are FSH receptor negative; monoclonal antibody CD45 was also used to enable the subtraction of the cells positive for the leukocyte common antigen in order to render a homogeneous population of granulosa cells. Atretic bodies formed by budding of the cytoplasm of apoptotic granulosa cells would also not have FSH receptors. Apoptosis would therefore be measured only in antral granulosa cells from the membrana and antral granulosa cells loosley attached to the granulosa membrana undergoing terminal differentiation. Basal granulosa cells would be excluded because of the distance from the atrum and the limited aspiration applied during collection to preserve the follicles with potential to form a corpus luteum. The cumulus cells form clumps and are usually attached to the oocyte forming the cumulus oocyte complex, and would be removed. The cumulus cells require hyloronidase to separate them from the oocyte for oocyte incubation during in vitro fertilisation (IVF). If the cells were not attached to the oocyte, they too would gated out during flow cytometry due to the large size of cumulus cell clumps.

FSH receptor and BMPR1B immunostaining was performed in separate tubes, and the Alexa 488 (emmission 519) spectral overlap with 7AAD on the far right of the spectrum was insignificant (emmission 647). Therefore, the proportion of 7AAD positve cells was considered to represent the base rate turnover of apoptosis of healthy (FSH receptor expression) granulosa cells (Fig. 1). The assessment would not account for the phagocytised or autophagocytosed granulosa cells. The data were analysed using FlowJo software (Tree Star Inc., Oregon, USA).

\subsection{Statistics}


181 Mean fluorescent intensity was obtained using $~ 8000$ granulosa cells per individual follicle for the direct

182 measurement of receptor protein expression. The data were subjected to statistical verification using one-

183 way ANOVA with an uncorrected Fisher's LSD for follicular size using GraphPad Prism 6. Values in

184 graphs are means \pm S.E.M., and differences were considered significant if $* p<0.05,{ }^{* *} p<0.01$,

$185 * * * \mathrm{p}<0.005$, and $* * * * \mathrm{p}<0.001$. A two tailed, student t-test was also used.

186

187

\subsection{Human Ethics}

188 Informed consent was obtained from patients undergoing standard fertility treatment at PIVET Medical

189 Centre, Perth, Australia, and from three patients undergoing risk reduction removal of the uterus and

190 ovaries, who were recruited from King Edward Memorial Hospital (KEMH) Perth, Australia. Approval

191 by the Human Research Ethics Committee of Curtin University of Technology and KEMH Women and

192 Newborn Health Service ethics committee was obtained for this study (HR RD26-10:2010-2016), and all

193 methods were performed in accordance with the relevant guidelines and regulations. 
194

195

\section{Results}

It should be emphasized that the percentage of apoptotic cells amongst the pure population of FSH receptor-expressing granulosa cells was determined here, and not the percentage of the total heterogeneous population of cells contained in the aspirated follicular fluid. In the young patient group, 23-30y with a typically good ovarian reserve that was indirectly measured by day 5 antral follicle count (AFC; groups $\mathrm{A}+\& \mathrm{~A})$. The level of apoptosis was higher in the granulosa cells from $10 \mathrm{~mm}$ follicles of which size, corresponds with the stage of dominant follicle selection ( $p<0.01$, Fig. 2). In the largest preovulatory follicles $(23-30 \mathrm{~mm})$, the percentage of granulosa cell apoptosis was also significantly greater $(\mathrm{p}<0.005)$ than at all other stages. A direct comparison between the level of receptor expression and the level of apoptosis can be made using previously published data (Fig. 2) (Regan et al., 2016,Regan et al., 2017). The analysis of apoptosis was performed on the same isolated granulosa cells as that for the receptor expression density. In the older patients, the lower level of apoptosis in the $10 \mathrm{~mm}$ follicles corresponded to the significantly reduced granulosal BMPR1B density, whereas the low level of apoptosis in the largest follicles (>23 mm) was associated with the lack of down-regulation of the BMPR1B, FSH receptor, and the LH receptor combined (Fig. 2).

At the stage of dominant follicle selection $(10 \mathrm{~mm})$, the level of apoptosis was reduced in the older age group 35-45y, with a typical depleted ovarian reserve of D \& E, compared to the youngest patients $(\mathrm{p}<0.005)$. The level of apoptosis was also greatly reduced ( 7-fold) in the largest pre-ovulatory follicles $>23 \mathrm{~mm}$ in size compared to similar sized follicles in the younger patients $(\mathrm{p}<0.0001$, Fig. 2). The level of apoptosis in the old compared to the young females was not significantly different at stages between dominant follicle selection and maturation of the largest follicles (14 $\mathrm{mm}$ to $19 \mathrm{~mm}, \mathrm{p}>0.1$, Fig. 3).

Since most of the comparative studies published have 'pooled' the follicles, in an attempt to compare our results, we combined the follicles of different size for the old compared to the young and this confirms a greater level of apoptosis in the younger patients ( $p<0.0001$, Fig. 4). 
When patients of the same age, $(40+y)$ with the same follicle size and ovarian reserve (AFC D) were compared, age alone was not predictive of apoptosis levels based on the finding that patients of the same age had significantly different apoptosis levels. Patients $40+y$ with a good ovarian reserve for age had levels of apoptosis $\sim 2$-fold higher than those with a poorer ovarian reserve $(\mathrm{p}<0.01$, Fig. 5). The dose of rFSH administered to patients did not have a significant effect on the apoptosis of the granulosa cells (p>0.2, Fig. 6).

The follicles of the similar size class were combined from patients based on age and ovarian reserve. A strong correlation was observed between the granulosal FSH receptor and BMPR1B density and the corresponding level of apoptosis based on follicle size (Fig. 7). High levels of FSHR and BMPR1B density were significantly associated with reduced apoptosis and necrosis levels in the youngest patients of 23-30 y with an AFC of $\mathrm{A}+\& \mathrm{~A}(\mathrm{R}$ square $0.752, \mathrm{p}=0.0252$ and $0.835, \mathrm{p}=0.0108$, respectively). The correlation was reversed in the next age group of 31-34 y for both FSHR and BMPR1B, and sequentially reduced in association with increasing age and a reducing ovarian reserve. In the $40+y$ patients, the nonsignificant correlation for apoptosis with FSH receptor and BMPR1B was R square $0.137, \mathrm{p}=0.86$ and $0.011, \mathrm{p}=0.46$, respectively. 


\section{Discussion}

237

The major findings of this study are that the level of granulosa cell apoptosis increased in follicles of a size corresponding to the stage of dominant follicle selection $(10 \mathrm{~mm})$ and of pre-ovulatory maturation $(23+\mathrm{mm})$ in young IVF patients with an uncompromised ovarian reserve based on the number or antral follicles present on day 5 of a cycle (AFC) (Fig. 2). The granulosal BMPR1B and FSH receptor density were both inversely proportional to the level of granulosal apoptosis in the young patients (Fig. 2). However, as the ovarian reserve declined with age, this relationship was disrupted. The reduction of apoptosis in the older patients was associated with a compromised level of BMPR1B at the time of dominant follicle selection $(10 \mathrm{~mm})$, whereas the low level of apoptosis in the largest follicles $(23+\mathrm{mm})$ was associated with the lack of down-regulation of the BMPR1B, FSH receptor, and the LH receptor combined (Fig. 2).

Unique to this study, only granulosa cells identified by FSH receptors on the cell surface were included in the flow cytometry analyses, providing certainty that the positive events were granulosa cell-specific after removal of both red and white blood cells and other potential confounding signals. In the current study, we do not differentiate between apoptosis or terminally differentiated granulosa cells, as 7AAD would stain all exposed DNA. The follicles analysed in the present study are healthy follicles that would be contributing to the overall serum oestrogen levels (Tilly J L et al., 1992,Amsterdam et al., 2003). The percentage of apoptosis reported would therefore not be comparable to studies that did not identify granulosa cells positively and that did not exclude white blood cells.

In the entire research project there were only four out of 500 follicles that were atretic and did not express any receptors, and were therefore removed from analysis. This is consistent with other studies that reported low levels of TUNEL assay positive granulosa cells in dominant follicles (Yuan and Giudice, 1997,Austin et al., 2001,Albamonte et al., 2013,Poljicanin, Vukusic Pusic, Vukojevic et al., 2013). In healthy dominant follicles, indicated by high oestrogen levels, apoptotic granulosa would not 
stain positively with TUNEL, propidium iodide or 7AAD, because they are continuously engulfed by neighbouring granulosa cells via phagocytosis (Van Wezel et al., 1999). Therefore, the level of apoptosis indicated by 7AAD +ve DNA in each follicle is more representative of the mitogenic activity within each follicle. As we age all of our cells multiply at a slower rate, hence the turnover rate is slower (Santoro et al., 2003,Seifer, 1996 ,Acosta, Jernberg, Sanberg et al., 2010). The lower levels of apoptosis in the older patients are reflective of the reduced proliferation occurring (Santoro et al., 2003).

At the time of dominant follicle selection in a natural cycle, the circulating FSH decreases, and the small growing follicles with greater FSH receptor and LH receptor density are stimulated to produce oestrogen and exhibit more cell proliferation at the expense of the subordinate follicles (Mihm, Baker, Ireland et al., 2006). In the young patients, a significant increase in 7AAD + granulosa cell death was evident in follicles around the size at which dominant follicle selection occurs (Fig. 2). FSH has been reported to be anti-apoptotic (Amsterdam, Keren-Tal, Aharoni et al., 2003); therefore, it may be expected that the decline in pituitary FSH initiates and/or contributes to an increase in apoptotic signalling in these granulosa cells (mid-follicular phase; day 7) (Xu, Garverick, Smith et al., 1995,Billig, Chun, Eisenhauer et al., 1996,Billig, Furuta and Hsueh, 1994).

In a gonadotrophin stimulated IVF cycle, high doses of rFSH are administered that override the natural changes in endogenous FSH, but the dose of rFSH did not exert a significant influence on granulosa apoptosis (Fig. 6). We have also previously demonstrated that the FSH receptor and LH receptor are down-regulated, independently of the gonadotrophins administered at the crucial time of dominant follicle selection (Regan et al., 2017), supported by a similar down-regulation mRNA for FSH receptor and BMPR1B in cumulus granulosa cells (Coticchio, Ophir, Yung et al., 2017). Therefore, at this critical time point, the FSH receptor expression is down-regulated (Fig. 2), which may explain the lower apoptosis rate as a consequence of reduced proliferation (Sen, Prizant, Light et al., 2014,Rice, Ojha, Whitehead et al., 2007). Hence in the younger patients, down-regulation of FSH receptors at the time of 
dominant follicle selection is consistent with a corresponding increase in apoptosis (Fig 2 and Fig. 5). As the levels of FSH receptor decrease, the granulosa cell would produce less oestrogen and show limited cell division. As the level of receptors increase, again the level of apoptosis reduces, which is consistent with our findings (Fig 2 and, Fig. 5).

When the ovarian reserve declines with age, it is evident that the level of FSH receptor or LH receptor in the small follicles is not compromised (Regan et al., 2017). Whereas, in the same patient cohort, a distinct difference in granulosal BMPR1B density was reported (Regan et al., 2016).Therefore, it is probable that the age-induced effect of reduced BMPR1B density is functionally linked to the level of granulosa cell apoptosis at the time of dominant follicle selection.

Previous research has shown that a reduction in follicular BMP6, BMP15, and BMPR1B coincides with dominant follicle selection (Regan et al., 2015,Regan et al., 2016,Erickson and Shimasaki, 2003,Feary, Juengel, Smith et al., 2007). In addition, BMP4 and 7 are involved at several stages of apoptotic signalling, in particular, the caspase 3 and 9 pathways (Kayamori, Kosaka, Miyamoto et al., 2009). Moreover, BMP2, 6, and 7 have been shown to up-regulate FSH receptor expression (Shi, Yoshino, Osuga et al., 2011,Shi, Yoshino, Osuga et al., 2009). Therefore, it is proposed that down-regulation in BMPR1B signalling would indirectly induce apoptosis, which is consistent with our reported high level of apoptosis in the younger patients (Fig 2).

In young wild type sheep, down-regulation of granulosal BMPR1B during dominant follicle selection was associated with an increased proportion of granulosa cell apoptosis (7AAD + / FSH receptor +) (Regan et al., 2015). Likewise, in the Booroola sheep, higher granulosal BMPR1B density was associated with reduced apoptosis and fewer granulosa cells per follicle (Regan et al., 2015,McNatty, Lun, Heath et al., 1986) . Our finding of a Booroola mutation-induced lowering of granulosa cell 
apoptosis levels associated with the high ovulation rate of this breed was recently confirmed (Estienne,

314 Pierre, di Clemente et al., 2015). In the human context, the lower levels, and reversed expression of

315 BMPR1B in the older patients, may directly contribute to low levels of apoptosis associated with poor

316 granulosa cell proliferation (Fig 2).

The extent of granulosa cell apoptosis was maintained at a consistent level in the follicles from 14 to 19 $\mathrm{mm}$ in size in the young cohort, which was not significantly different to that seen with the older patients (Fig. 3). The plateau could signify a base rate of continuous removal of atretic granulosa cells via phagocytosis or autophagy and terminal sloughing off of granulosa cells into the antrum. Importantly, the similar levels of apoptosis in the older patients suggest that the general health of the follicle is not compromised.

In contrast, in a study using TUNEL labelling in aspirated follicles from IVF patients, Seifer, et al, 1996, reported that granulosa cell apoptosis was increased as the ovarian reserve declined. These cells were contaminated with white blood cells, and when counterstained with propidium iodide, this quadrant was not included. In another study of IVF stimulated patients (33 year-old), annexin V staining indicated that the level of apoptosis was $7.8-9.8 \%$; however, the propidium iodide stained quadrant was excluded from analysis (Giampietro et al., 2006). In addition, the follicles were centrifuged at $3000 \mathrm{rpm}(1200 \mathrm{~g})$ and were pooled; whereas, in the current study, the follicles were individually analysed $(\sim 8000$ granulosa FSH receptor positive cells per follicle) and centrifuged at $1500 \mathrm{rpm}$ (300 g). The same study applied a second method (TUNEL assay) on the same patient group, and the level was found to be much higher, $20 \%$ (Giampietro et al., 2006). The authors acknowledged that the TUNEL assay may also overestimate apoptosis because multiple atretic bodies measured may have originated from a single granulosa cell. The TUNEL assay also estimated apoptosis levels to be higher than that assessed by 
when reporting and comparing results using different methodologies, and raises caution with regard to experimentally induced errors.

Surprisingly, the level of apoptosis in the largest follicles $(>23 \mathrm{~mm})$ from the young patients was significantly higher compared to middle sized follicles (Fig. 2). The greater level of apoptosis coincides with the extensive morphological changes that take place in the preovulatory stage to facilitate the rupture of the follicle and expulsion of the oocyte (Fig. 2) (Fan, Liu, Shimada et al., 2009). Even though all the follicles are exposed to the same LH/HCG surge trigger injection, the 'extent of luteinisation' is dependent on the size of the follicle (Regan et al., 2017). Preparation for ovulation begins with a cessation of cell proliferation and early luteinisation. This may cause antral granulosa cells to become apoptotic in the young. For example, the antral granulosa membrana thins out at the surface of the ovary in preparation for rupture(Rodgers and Irving-Rodgers, 2010). This remodelling would increase the apoptosis of antral granulosa cells. In contrast, in the older patients the receptors were not downregulated which may influence or delay this remodelling process, and result in reduced apoptosis observed in the older patient.

Conflicting with the current study, an increase in DNA fragmentation of granulosa cells (TUNEL assay) has been shown to increase with age, even though errors in methodologies were present, as described above (Oosterhuis et al., 1998,Seifer, 1996 ,Sadraie, Saito, Kaneko et al., 2000). As the granulosa cell differentiates into a progesterone producing granulosa-lutein cell, the oestrogen levels also transiently decline. The decline in oestrogen and other growth factors may account for the increased apoptosis in the largest follicle in the young because this follicle would have the greatest drop in oestrogen (Fig. 2).

Whereas, maturation of the pre-ovulatory follicle requires down-regulation of the BMPR1B, FSH receptor, and LH receptor (Cai et al., 2007,Regan et al., 2015,Regan et al., 2016,Regan et al., 2017,Feary 
et al., 2007,LaPolt and Lu, 2001, Ophir, Yung, Maman et al., 2014). The lack of down-regulation of the

364 receptors combined observed in the older patients (as previously described) would limit the maturation of the follicle and maintain a high anti-apoptotic state, consistent with the reduced apoptosis level (Fig 2).

In the current study, we did not find an increase in granulosa cell apoptosis in the large ( $>23 \mathrm{~mm})$ preovulatory follicles of older patients that had a poor ovarian reserve (antral follicle count-D\&E). These patients also had a poor pregnancy and live birth rate (Fig. 2). This is in marked contrast to the finding in the younger patients who showed a $\sim 7$-fold higher level of apoptosis in follicles of the same size class (>23 mm) (Fig. 2). Moreover, when the individual results for each follicle size were combined to mimic results from a 'pooled follicle protocol', the younger patients still had a significantly greater level $(\sim 2-$ fold) of 7AAD positive cells (Fig. 4); notwithstanding that, they were uniquely identified as granulosa cells that were FSH receptor positive and free from white blood cell contamination.

Disregarding different methodologies and experimental errors, there are considerable discrepancies in the literature. Increased apoptosis of pooled granulosa cells has been linked to poor oocyte quality and pregnancy rate (Nakahara et al., 1997,Oosterhuis et al., 1998,Clavero, Castilla, Núñez et al., 2003,Suh, Jee, Choi et al., 2002), greater apoptosis in cumulus cells (Lee et al., 2001), and increased oxidative stress (Wiener-Megnazi et al., 2004). However, granulosa cell apoptosis rate has also been reported to have no association with oocyte quality, fertilisation rate or blastocyst development, (Jančar et al., 2007,Moffatt et al., 2002,Clavero et al., 2003).

In support of our findings Nakahara, et al, 1997, reports that when age alone was examined, the 40+y patients had significantly reduced apoptosis of the granulosa cells. Interestingly, when age was removed and the number of oocytes stimulated were the same, apoptosis was related to pregnancy outcome and 
not the ovarian reserve (Oosterhuis et al., 1998). Oosterhuis et al, 1998, reported that pregnancy rate was associated with reduced granulosa apoptosis levels (TUNEL assay); conversely, Moffatt et al, 2002, reported that the apoptosis level in cumulus cells from oocytes that were inseminated was higher than in abnormal oocytes, immature or mature oocytes, which indicate that the mechanisms involved in fertilisation induce apoptosis during normal function.

It is noteworthy that despite the initial impetus for apoptosis research as a clinical measure of oocyte quality, this has not been translated into clinical practice in IVF medical centres. The accuracy of apoptosis as a marker for superior oocyte quality and the commercial need for rapid outcome based procedures has limited translational research in this area.

Ovarian reserve and the density of FSH and LH receptors have been linked with reduced fertility and oocyte quality (Cai et al., 2007,Maman, Yung, Kedem et al., 2012). In addition, the dysregulation of gene expression of granulosal BMPR1B, FSH, and $\mathrm{LH}$ receptors from older patients has been associated with poor pregnancy rate (Regan et al., 2016,Regan et al., 2017). On the basis of the current findings, dysregulation of receptor expression in the older patient may supress the mitogenic growth rate in healthy follicles indicated by reduced granulosa cell apoptosis. BMPR1B levels were reduced at the critical time of dominant follicle selection and the lack of down-regulation of BMPR1B, FSH and LH receptors involved in preovulatory maturation were associated with lower granulosa apoptosis rates and infertility. Restoring an optimum receptor density and down-regulation of receptors may improve the pregnancy rate in older women.

\section{Authors' roles}

SLPR conceived the study, experimental design, conducted all experiments, the analysis and interpretation of data, wrote the first draft of the manuscript and the final version of the paper, and 
obtained informed consent from patients and ethics approval. PK interpretation of data, contributed to

414 the draft of the manuscript, and critically revised the manuscript. JLY supervised, participated in the

415 study design, interpretation of data, and critically revised the manuscript. YL supervised, participated in

416 the study design, obtained informed consent from patients and ethics approval, and revised the

417 manuscript. FA supervised, contributed to the draft of the manuscript, interpretation of data, and

418 critically revised the manuscript. GA supervised, participated in the study design, interpretation of data,

419 and revised the manuscript. AD supervised, participated in the study design, interpretation of data,

420 contributed to the draft of the manuscript, and critically revised the manuscript.

\section{Funding}

S.L.P.R. was a recipient of an Australian Postgraduate Award and a Curtin University Postgraduate

Scholarship. This work was supported by additional private external funding, which was gratefully

accepted from Denby Macgregor.

\section{5}

426

427

428

429

430

431

432

433

434

435

436

437

438

439

440

441

442

443

444

445

446

447

\section{Conflict of interest}

The authors declare that there is no conflict of interest that could be perceived as prejudicing the impartiality of the research reported.

\section{References}

[1] Hsueh, A.J.W., Kawamura, K., Cheng, Y. and Fauser, B.C.J.M., 2015. Intraovarian Control of Early Folliculogenesis, Endocrine Reviews. 36, 1-24.

[2] Al-Musawi, S.L., Gladwell, R.T. and Knight, P.G., 2007. Bone morphogenetic protein-6 enhances gonadotrophin-dependent progesterone and inhibin secretion and expression of mRNA transcripts encoding gonadotrophin receptors and inhibin/activin subunits in chicken granulosa cells, Reproduction. 134, 293-306.

[3] Di Pasquale, E., Beck-Peccoz, P. and Persani, L., 2004. Hypergonadotropic ovarian failure associated with an inherited mutation of human bone morphogenetic protein-15 (BMP15) gene, Am J Hum Genet. 75, 106 - 111.

[4] Cai, J., Lou, H., Dong, M., Lu, X., Zhu, Y., Gao, H. and Huang, H., 2007. Poor ovarian response to gonadotropin stimulation is associated with low expression of follicle-stimulating hormone receptor in granulosa cells, Fertility and Sterility. 87, 1350-1356.

[5] Nelson, S.M., Telfer, E.E. and Anderson, R.A., 2013. The ageing ovary and uterus: new biological insights, Human Reproduction Update. 19, 67-83.

[6] Tilly J L, Billig H , Kowalski K I and Hsueh A J 1992. Epidermal growth factor and basic fibroblast growth factor suppress the spontaneous onset of apoptosis in cultured rat ovarian granulosa cells and follicles by a tyrosine kinase-dependent mechanism, Molecular Endocrinology. 6, 1942-1950.

[7] Santoro, N., Isaac, B., Neal-Perry, G., Adel, T., Weingart, L., Nussbaum, A., Thakur, S., Jinnai, H., Khosla, N. and Barad, D., 2003. Impaired Folliculogenesis and Ovulation in Older Reproductive Aged Women, The Journal of Clinical Endocrinology \& Metabolism. 88, 55025509. 
[8] Seifer, D.B., Scott Jr, R.T., Bergh, P.A., Abrogast, L.K., Friedman, C.I., Mack, C.K. and Danforth, D.R., 1999. Women with declining ovarian reserve may demonstrate a decrease in day 3 serum inhibin B before a rise in day 3 follicle-stimulating hormone, Fertility and Sterility. 72, 63-65.

[9] Robertson, D., Hale, GE, Jolley, D, Frase,r IS, Hughes, CL, Burger, HG, 2009. Interrelationships between Ovarian and Pituitary Hormones in Ovulatory Menstrual Cycles across Reproductive Age, The Journal of Clinical Endocrinology \& Metabolism. 94, 138-144.

[10] MacNaughton, J., Banah, M., McCloud, P., Hee, J. and Burger, H., 1992. Age related changes in follicle stimulating hormone, luteinizing hormone, oestradiol and immunoreactive inhibin in women of reproductive age, Clinical endocrinology. 36, 339-345.

[11] Vanden Brink, H., Robertson, D.M., Lim, H., Lee, C., Chizen, D., Harris, G., Hale, G., Burger, H. and Baerwald, A., 2015. Associations Between Antral Ovarian Follicle Dynamics and Hormone Production Throughout the Menstrual Cycle as Women Age, The Journal of Clinical Endocrinology \& Metabolism. 100, 4553-4562.

[12] Yuan, W. and Giudice, L., 1997. Programmed Cell Death in Human Ovary Is a Function of Follicle and Corpus Luteum Status, The Journal of Clinical Endocrinology \& Metabolism. 82, 3148-3155.

[13] Bencomo, E., Pérez, R., Arteaga, M.-F., Acosta, E., Peña, O., Lopez, L., Avila, J. and Palumbo, A., 2006. Apoptosis of cultured granulosa-lutein cells is reduced by insulin-like growth factor I and may correlate with embryo fragmentation and pregnancy rate, Fertility and Sterility. 85, 474-480.

[14] Sasson, R. and Amsterdam, A., 2002. Stimulation of apoptosis in human granulosa cells from in vitro fertilization patients and its prevention by dexamethasone: involvement of cell contact and bcl-2 expression, J Clin Endocrinol Metab. 87, 3441 - 3451.

[15] Irving-Rodgers, H.F., Krupa, M. and Rodgers, R.J., 2003. Cholesterol Side-Chain Cleavage Cytochrome P450 and 3 $\beta$-Hydroxysteroid Dehydrogenase Expression and the Concentrations of Steroid Hormones in the Follicular Fluids of Different Phenotypes of Healthy and Atretic Bovine Ovarian Follicles, Biology of Reproduction. 69, 2022-2028.

[16] Jančar, N., Kopitar, A.N., Ihan, A., Klun, I.V. and Bokal, E.V., 2007. Effect of apoptosis and reactive oxygen species production in human granulosa cells on oocyte fertilization and blastocyst development, Journal of Assisted Reproduction and Genetics. 24, 91-97.

[17] Lee, K.S., Joo, B.S., Na, Y.J., Yoon, M.S., Choi, O.H. and Kim, W.W., 2001. Clinical Assisted Reproduction: Cumulus Cells Apoptosis as an Indicator to Predict the Quality of Oocytes and the Outcome of IVF-ET, Journal of Assisted Reproduction and Genetics. 18, 490-498.

[18] Nakahara, K., Saito, H., Saito, T., Ito, M., Ohta, N., Takahashi, T. and Hiroi, M., 1997. The incidence of apoptotic bodies in membrana granulosa can predict prognosis of ova from patients participating in in vitro fertilization programs, Fertility and Sterility. 68, 312-317.

[19] Oosterhuis, G.J.E., Michgelsen, H.W., Lambalk, C.B., Schoemaker, J. and Vermes, I., 1998. Apoptotic cell death in human granulosa-lutein cells: a possible indicator of in vitro fertilization outcome, Fertility and Sterility. 70, 747-749.

[20] Moffatt, O., Drury, S., Tomlinson, M., Afnan, M. and Sakkas, D., 2002. The apoptotic profile of human cumulus cells changes with patient age and after exposure to sperm but not in relation to oocyte maturity, Fertility and Sterility. 77, 1006-1011.

[21] Wiener-Megnazi, Z., Vardi, L., Lissak, A., Shnizer, S., Zeev Reznick, A., Ishai, D., LahavBaratz, S., Shiloh, H., Koifman, M. and Dirnfeld, M., 2004. Oxidative stress indices in follicular fluid as measured by the thermochemiluminescence assay correlate with outcome parameters in in vitro fertilization, Fertility and Sterility. 82, 1171-1176.

[22] Hyman, J.H., Margalioth, E.J., Rabinowitz, R., Tsafrir, A., Gal, M., Alerhand, S., Algur, N. and Eldar-Geva, T., 2013. DHEA supplementation may improve IVF outcome in poor responders: a proposed mechanism, European Journal of Obstetrics \& Gynecology and Reproductive Biology. $168,49-53$.

[23] Van Wezel, Dharmarajan AM, Lavranos TC and Rodgers RJ, 1999. Evidence for alternative pathways of granulosa cell death in healthy and slightly atretic bovine antral follicles, Endocrinology. 140, 2602-12. 
[24] van Wezel, I.L., Rodgers, R.J. and Krupa, M., 1999. Development of the membrana granulosa of bovine antral follicles: structure, location of mitosis and pyknosis, and immunolocalization of involucrin and vimentin, Reproduction, Fertility and Development. 11, 37-48.

[25] Hay, M.F., Cran, D.G. and Moor, R.M., 1976. Structural changes occurring during atresia in sheep ovarian follicles, Cell and Tissue Research. 169, 515-529.

[26] Duerrschmidt, N., Zabirnyk, O., Nowicki, M., Ricken, A., Hmeidan, F.A., Blumenauer, V., Borlak, J.r. and Spanel-Borowski, K., 2006. Lectin-Like Oxidized Low-Density Lipoprotein Receptor-1-Mediated Autophagy in Human Granulosa Cells as an Alternative of Programmed Cell Death, Endocrinology. 147, 3851-3860.

[27] Vilser, C., Hueller, H., Nowicki, M., Hmeidan, F.A., Blumenauer, V. and Spanel-Borowski, K., 2010. The variable expression of lectin-like oxidized low-density lipoprotein receptor (LOX-1) and signs of autophagy and apoptosis in freshly harvested human granulosa cells depend on gonadotropin dose, age, and body weight, Fertility and Sterility. 93, 2706-2715.

[28] Seifer, D., Gardiner, AC, Ferreira, KA, Peluso, JJ., 1996 Apoptosis as a function of ovarian reserve in women undergoing in vitro fertilization., Fertil Steril. . 66(4), 593-8.

[29] Giampietro, F., Sancilio, S., Tiboni, G.M., Rana, R.A. and Di Pietro, R., 2006. Levels of apoptosis in human granulosa cells seem to be comparable after therapy with a gonadotropinreleasing hormone agonist or antagonist, Fertility and Sterility. 85, 412-419.

[30] Austin, E.J., Mihm, M., Evans, A.C.O., Knight, P.G., Ireland, J.L.H., Ireland, J.J. and Roche, J.F., 2001. Alterations in Intrafollicular Regulatory Factors and Apoptosis During Selection of Follicles in the First Follicular Wave of the Bovine Estrous Cycle, Biology of Reproduction. 64, 839-848.

[31] Bomsel-Helmreich, O., Gougeon, A., Thebault, A., Saltarelli, D., Milgrom, E., Frydman, R. and Papiernik, E., 1979. Healthy and atretic human follicles in the preovulatory phase: differences in evolution of follicular morphology and steroid content of follicular fluid, The Journal of clinical endocrinology and metabolism. 48, 686-694.

[32] D'haeseleer, M., Cocquyt, G., Cruchten, S.V., Simoens, P. and Broeck, W.V.D., 2006. Cellspecific localisation of apoptosis in the bovine ovary at different stages of the oestrous cycle, Theriogenology. 65, 757-772.

[33] Albamonte, M.I., Albamonte, M.S., Stella, I., Zuccardi, L. and Vitullo, A.D., 2013. The infant and pubertal human ovary: Balbiani's body-associated VASA expression, immunohistochemical detection of apoptosis-related BCL2 and BAX proteins, and DNA fragmentation, Human Reproduction. 28, 698-706.

[34] Regan, S.L.P., McFarlane, J.R., O'Shea, T., Andronicos, N., Arfuso, F., Dharmarajan, A. and Almahbobi, G., 2015. Flow cytometric analysis of FSHR, BMRR1B, LHR and apoptosis in granulosa cells and ovulation rate in merino sheep, Reproduction. 150, 151-163.

[35] Regan, S.L.P., Knight, P.G., Yovich, J., Stanger, J., Leung, Y., Arfuso, F., Dharmarajan, A. and Almahbobi, G., 2016. Dysregulation of granulosal bone morphogenetic protein receptor 1B density is associated with reduced ovarian reserve and the age-related decline in human fertility, Molecular and Cellular Endocrinology. 425, 84-93.

[36] Hansen, K.R., Hodnett, G.M., Knowlton, N. and Craig, L.B., 2011. Correlation of ovarian reserve tests with histologically determined primordial follicle number, Fertility and Sterility. 95, 170-175.

[37] Yovich, J., Stanger, J. and Hinchliffe, P., 2012. Targeted gonadotrophin stimulation using the PIVET algorithm markedly reduces the risk of OHSS, Reproductive BioMedicine Online. 24, 281-292.

[38] Regan, S.L.P., Knight, P.G., Yovich, J.L., Stanger, J.D., Leung, Y., Arfuso, F., Dharmarajan, A. and Almahbobi, G., 2017. Infertility and ovarian follicle reserve depletion are associated with dysregulation of the FSH and LH receptor density in human antral follicles, Molecular and Cellular Endocrinology. 446, 40-51.

[39] Al-Samerria, S. and Almahbobi, G., 2014 Three-dimensional image analysis to quantify the temproro-smacial expression of cellular receptors, Journal of Medical and Bioengineering 3, 179-182. 
[40] Demchenko, A., 2013. Beyond annexin V: fluorescence response of cellular membranes to apoptosis, Cytotechnology. 65, 157-172.

[41] Amsterdam, A., Sasson, R., Keren Tal, I., Aharoni, D., Dantes, A., Rimon, E., Land, A., Cohen, T., Dor, Y. and Hirsh, L., 2003. Alternative pathways of ovarian apoptosis: death for life, Biochemical pharmacology. 66, 1355-1362.

[42] Vermes, I., Haanen, C., Steffens-Nakken, H. and Reutellingsperger, C., 1995. A novel assay for apoptosis Flow cytometric detection of phosphatidylserine expression on early apoptotic cells using fluorescein labelled Annexin V, Journal of Immunological Methods. 184, 39-51.

[43] Hermann, B.P. and Heckert, L.L., 2007. Transcriptional regulation of the FSH receptor: New perspectives, Molecular and Cellular Endocrinology. 260-262, 100-108.

[44] Poljicanin, A., Vukusic Pusic, T., Vukojevic, K., Caric, A., Vilovic, K., Tomic, S., Soljic, V. and Saraga-Babic, M., 2013. The expression patterns of pro-apoptotic and anti-apoptotic factors in human fetal and adult ovary, Acta Histochemica. 115, 533-540.

[45] Acosta, S., Jernberg, J., Sanberg, C.D., Sanberg, P.R., Small, B.J., Gemma, C. and Bickford, P.C., 2010. NT-020, a Natural Therapeutic Approach to Optimize Spatial Memory Performance and Increase Neural Progenitor Cell Proliferation and Decrease Inflammation in the Aged Rat, Rejuvenation Research. 13, 581-588.

[46] Mihm, M., Baker, P.J., Ireland, J.L.H., Smith, G.W., Coussens, P.M., Evans, A.C.O. and Ireland, J.J., 2006. Molecular Evidence That Growth of Dominant Follicles Involves a Reduction in Follicle-Stimulating Hormone Dependence and an Increase in Luteinizing Hormone Dependence in Cattle, Biology of Reproduction. 74, 1051-1059.

[47] Amsterdam, A., Keren-Tal, I., Aharoni, D., Dantes, A., Land-Bracha, A., Rimon, E., Sasson, R. and Hirsh, L., 2003. Steroidogenesis and apoptosis in the mammalian ovary, Steroids. 68, 861867.

[48] Xu, Z., Garverick, H.A., Smith, G.W., Smith, M.F., Hamilton, S.A. and Youngquist, R.S., 1995. Expression of follicle-stimulating hormone and luteinizing hormone receptor messenger ribonucleic acids in bovine follicles during the first follicular wave, Biology of Reproduction. 53, 951-957.

[49] Billig, H., Chun, S., Eisenhauer, K. and Hsueh, A., 1996. Gonadal cell apoptosis: hormoneregulated cell demise, Human Reproduction Update. 2, 103-117.

[50] Billig, H., Furuta, I. and Hsueh, A.J., 1994. Gonadotropin-releasing hormone directly induces apoptotic cell death in the rat ovary: biochemical and in situ detection of deoxyribonucleic acid fragmentation in granulosa cells, Endocrinology. 134, 245-252.

[51] Coticchio, G., Ophir, L., Yung, Y., Baum, M., Dal Canto, M., Mignini-Renzini, M., Brambillasca, F., Fadini, R. and Hourvitz, A., 2017. Differential regulation of cumulus cell transcription during oocyte maturation in vivo and in vitro, Int. J. Dev. Biol. 61, 433 - 437.

[52] Sen, A., Prizant, H., Light, A., Biswas, A., Hayes, E., Lee, H.-J., Barad, D., Gleicher, N. and Hammes, S.R., 2014. Androgens regulate ovarian follicular development by increasing follicle stimulating hormone receptor and microRNA-125b expression, Proceedings of the National Academy of Sciences. 111(8), 3008-3013.

[53] Rice, S., Ojha, K., Whitehead, S. and Mason, H., 2007. Stage-specific expression of androgen receptor, follicle-stimulating hormone receptor, and anti-müllerian hormone type ii receptor in single, isolated, human preantral follicles: Relevance to polycystic ovaries, The Journal of Clinical Endocrinology \& Metabolism. 92, 1034-1040.

[54] Erickson, G. and Shimasaki, S., 2003. The spatiotemporal expression pattern of the bone morphogenetic protein family in rat ovary cell types during the estrous cycle, Reprod Biol Endocrinol. 1(9), 1-20.

[55] Feary, E., Juengel, J., Smith, P., French, M., O'Connell, A., Lawrence, S., Galloway, S., Davis, G. and McNatty, K., 2007. Patterns of expression of messenger RNAs encoding GDF9, BMP15, TGFBR1, BMPR1B, and BMPR2 during follicular development and characterization of ovarian follicular populations in ewes carrying the Woodlands FecX2W mutation, Biology of Reproduction. 77, 990-998. 
[56] Kayamori, T., Kosaka, N., Miyamoto, A. and Shimizu, T., 2009. The differential pathways of bone morphogenetic protein (BMP)-4 and -7 in the suppression of the bovine granulosa cell apoptosis, Molecular and cellular biochemistry. 323, 161-168.

[57] Shi, J., Yoshino, O., Osuga, Y., Koga, K., Hirota, Y., Nose, E., Nishii, O., Yano, T. and Taketani, Y., 2011. Bone morphogenetic protein-2 (BMP-2) increases gene expression of FSH receptor and aromatase and decreases gene expression of LH receptor and StAR in human granulosa cells, American journal of reproductive immunology (1989). 65, 421-427.

[58] Shi, J., Yoshino, O., Osuga, Y., Koga, K., Hirota, Y., Hirata, T., Yano, T., Nishii, O. and Taketani, Y., 2009. Bone morphogenetic protein-6 stimulates gene expression of folliclestimulating hormone receptor, inhibin/activin beta subunits, and anti-M $\tilde{A} 1 / 41$ lerian hormone in human granulosa cells, Fertility and Sterility. 92, 1794-1798.

[59] McNatty, K., Lun, S., Heath, D., Ball, K., Smith, P., Hudson, N., McDiarmid, J., Gibb, M. and Henderson, K., 1986. Differences in ovarian activity between Booroola Merino ewes which were homozygous, heterozygous and non-carriers of a major gene influencing their ovulation rate, J Reprod Fertil. 77, 193 - 205.

[60] Estienne, A., Pierre, A., di Clemente, N., Picard, J.-Y., Jarrier, P., Mansanet, C., Monniaux, D. and Fabre, S., 2015. Anti-Müllerian Hormone Regulation by the Bone Morphogenetic Proteins in the Sheep Ovary: Deciphering a Direct Regulatory Pathway, Endocrinology. 156, 301-313.

[61] Fan, H., Liu, Z., Shimada, M., Sterneck, E., Johnson, P.F., Hedrick, S.M. and Richards, J.S., 2009. MAPK3/1 (ERK1/2) in ovarian granulosa cells are essential for female fertility, Science,. 324, 938-941.

[62] Rodgers, R. and Irving-Rodgers, H., 2010. Formation of the ovarian follicular antrum and follicular fluid, Biol Reprod. 82, 1021 - 1029.

[63] Sadraie, S.H., Saito, H., Kaneko, T., Saito, T. and Hiroi, M., 2000. Effects of Aging on Ovarian Fecundity in Terms of the Incidence of Apoptotic Granulosa Cells, Journal of Assisted Reproduction and Genetics. 17, 168-173.

[64] LaPolt, P.S. and Lu, J.K.H., 2001. Effects of aging on luteinizing hormone secretion, ovulation, and ovarian tissue-type plasminogen activator expression, Experimental biology and medicine. 226, 127-132.

[65] Ophir, L., Yung, Y., Maman, E., Rubinstein, N., Yerushalmi, G.M., Haas, J., Barzilay, E. and Hourvitz, A., 2014. Establishment and validation of a model for non-luteinized human mural granulosa cell culture, Molecular and Cellular Endocrinology. 384, 165-174.

[66] Clavero, A., Castilla, J.A., Núñez, A.I., García-Peña, M.L., Maldonado, V., Fontes, J., Mendoza, N. and Martinez, L., 2003. Apoptosis in human granulosa cells after induction of ovulation in women participating in an intracytoplasmic sperm injection program, European Journal of Obstetrics \& Gynecology and Reproductive Biology. 110, 181-185.

[67] Suh, C.S., Jee, B.C., Choi, Y.M., Kim, J.G., Lee, J.Y., Moon, S.Y. and Kim, S.H., 2002. Prognostic Implication of Apoptosis in Human Luteinized Granulosa Cells During IVF-ET, Journal of Assisted Reproduction and Genetics. 19, 209-214.

[68] Maman, E., Yung, Y., Kedem, A., Yerushalmi, G.M., Konopnicki, S., Cohen, B., Dor, J. and Hourvitz, A., 2012. High expression of luteinizing hormone receptors messenger RNA by human cumulus granulosa cells is in correlation with decreased fertilization, Fertility and Sterility. 97, 592-598. 


\section{Figure 1 Schematic diagram of analysis of data}

2 The study design detected 7AAD positive cells (+ve) that expressed FSH receptors localized

3 to the surface of the granulosa cell. FSH receptor positive cells are indicated by the pink halo

4 around the box. White blood cells (FSH receptors -ve), atretic bodies (isolated cytoplasm

5 content e.g. organelles, FSH receptor -ve), and terminally differentiated granulosa cells

6 coalesced into large globules (internalised FSH receptor -ve) would not be represented. To

7 retrieve the oocyte for fertilisation, the cumulus cells (FSH receptor +ve) are removed with

8 the cumulus oocyte complex. Basal granulosa cells (FSH receptor +ve) are unlikely to be

9 included because deep gouging of the granulosa membrana did not occur, as this would

10 compromise subsequent corpus luteum function.

11 Figure 2 Granulosal apoptosis and receptor levels in the young compared to older IVF 12 patients

13 Granulosal apoptosis and ovarian reserve depletion collected from different size follicles.

14 Percentage of 7AAD and FSH receptor positive granulosa cells from healthy follicles. The

15 level of apoptosis is defined as; the percentage of cells expressing FSH receptors that are

16 positive for exposed DNA (7AAD+), and not a percentage of the heterogeneous total

17 population of cells in the aspirated follicular fluid. All data were subjected to statistical

18 verification using one-way ANOVA with an uncorrected Fisher's LSD. Values are means \pm

19 S.E.M., and differences were considered significant if $* \mathrm{p}<0.05, * * \mathrm{p}<0.01, * * * \mathrm{p}<0.005$ and

$20 * * * * \mathrm{p}<0.0001$. The number within the column represents the number of follicles analysed

21 for that group. Patients were grouped according to ovarian reserve measured indirectly by

22 the antral follicle count (AFC). AFC is the number of follicles from 2-10 mm on day 2-5 of a

23 cycle. Follicle count is based on the combined total AFC from both ovaries. 


\section{Figure 3 Apoptosis rate of granulosa cells and ovarian reserve depletion in young}

\section{compared to older IVF patients}

Data were subjected to statistical verification using t-test. Values are means \pm S.E.M., and differences were considered significant if $\mathrm{p}<0.05$. The number within the column represents the number of follicles analysed for that group. The percentage of apoptosis is defined as the 7AAD + / FSHR + cells of the granulosa cell population expressing FSH receptors, and not the heterogeneous total population of cells in the aspirated follicular fluid.

\section{Figure 4 Granulosa apoptosis from follicles when combined.}

Individual follicles of different sizes for the young and old with a typical ovarian reserve for age were combined to mimic an experimental protocol of 'pooled' follicles. The percentage of apoptosis is defined as the 7AAD + / FSHR+ cells of granulosa cell population expressing FSH receptors, and not the heterogeneous total population of cells in the aspirated follicular fluid. Data were subjected to statistical verification using t-test. Values are means \pm S.E.M., and differences were considered significant if $p<0.05$. The number within the column represents the number of follicles analysed for that group.

\section{Figure 5 The effect of ovarian reserve depletion on granulosal apoptosis in 40+year old} IVF patients

Percentage of apoptotic granulosa cells and follicle size collected during IVF cycles. Patients were grouped according to ovarian reserve, measured indirectly by the antral follicle count (AFC). Antral follicle count is the number of follicles from 2-10 mm on day 2-5 of a cycle. Follicle count is based on the combined total from both ovaries. The percentage of apoptosis is defined as the 7AAD + / FSHR + cells of granulosa cell population expressing FSH receptors, and not the heterogeneous total population of cells in the aspirated follicular fluid. 
49 Data were subjected to statistical verification using one-way ANOVA with an uncorrected

50 Fisher's LSD. Values are means \pm S.E.M., and differences were considered significant if

$51 * \mathrm{p}<0.05, * * \mathrm{p}<0.01$ and $* * * \mathrm{p}<0.005$. The number within the column represents the number

52 of follicles analysed for that group.

54 Figure 6 The comparative effect of rFSH dose on FSH receptor and LH receptor

\section{5 expression}

56 The effect of dose of $\mathrm{rFSH}$ on granulosal apoptosis in patients matched for aged, ovarian

57 reserve, $\mathrm{AMH}$, and size of follicles: $40+\mathrm{y}$, with an ovarian reserve of $\mathrm{D}$, and follicle size of

$58 \quad 10-22 \mathrm{~mm}$. The percentage of apoptosis is defined as the 7AAD + / FSHR+ cells of

59 granulosa cell population expressing FSH receptors, and not the heterogeneous total

60 population of cells in the aspirated follicular fluid. Data were subjected to statistical

61 verification using t-test. Values are means \pm S.E.M., and differences were considered

62 significant if $\mathrm{p}<0.05$. The number within the column represents the number of follicles

63 analysed for that group.

65 Figure 7 Correlations of granulosal FSHR and BMPR1B density with apoptosis, and

66 the influence of declining ovarian reserve

67 Ovarian reserve, measured indirectly by the antral follicle count (AFC). AFC is the number

68 of follicles between 2-10 mm on day 2-5 of a cycle. Sequential graphs show increasing age

69 and declining ovarian reserve indicated by AFC. Mean fluorescent intensity (MFI) was

70 obtained using an average of $\sim 8000$ granulosa cells per follicle for the direct measurement of

71 receptor protein expression. The data were subjected to statistical verification using one-way

72 ANOVA with an uncorrected Fisher's LSD for follicular size. Linear regression analysis; R

73 squared is indicated for each group. The data points are the average of the receptor 
74 expression for the follicle size; patients combined. Values are means \pm S.E.M., and

75 differences were considered significant if $\mathrm{p}<0.05$.

76 
Table 1 Ovarian reserve, based on antral follicle count (AFC) and the number of follicles collected per group.

\begin{tabular}{|c|c|c|c|c|c|c|c|c|c|c|c|c|}
\hline \multirow[t]{2}{*}{$\begin{array}{l}\text { AGE } \\
\text { Year }\end{array}$} & \multirow[t]{2}{*}{$\begin{array}{c}\text { IVF } \\
\text { Patient }\end{array}$} & \multirow[t]{2}{*}{$\begin{array}{l}\text { Total } \\
\text { Follicle }\end{array}$} & \multirow[t]{2}{*}{ BMI } & \multicolumn{6}{|c|}{$\begin{array}{l}\text { Ovarian Reserve Group } \\
\text { Follicles Collected }\end{array}$} & \multicolumn{3}{|c|}{$\begin{array}{c}\text { Fertility } \\
\text { Per Embryo Transfer } \\
\%\end{array}$} \\
\hline & & & & At & A & B & C & D & $\mathbf{E}$ & $\begin{array}{c}\text { Not } \\
\text { Pregnant }\end{array}$ & Pregnant & $\begin{array}{l}\text { Live } \\
\text { Birth }\end{array}$ \\
\hline 23-30 & 9 & 64 & $24.1 \pm 4$ & 30 & 46 & 0 & 0 & $\mathbf{0}$ & $\mathbf{0}$ & 26 & $73 * *$ & 33 \\
\hline $35-45$ & 18 & 122 & $24.8 \pm 5$ & $\mathbf{0}$ & $\mathbf{0}$ & 34 & 5 & 67 & 16 & 79 & 21 & 7 \\
\hline$* 40-45$ & 9 & 83 & $23.9 \pm 5$ & 0 & 0 & 19 & 5 & 54 & 5 & 94 & 6 & 0 \\
\hline
\end{tabular}

Ovarian reserve measured indirectly by the Antral Follicle Count (AFC). AFC is the number of follicles between 2-10 mm on day 2-5 of a cycle: group $\mathrm{A}+=30-39$ follicles; group $\mathrm{A}=$ 20-29 follicles; group $\mathrm{B}=13-19$ follicles; group $\mathrm{C}=$ 9-12 follicles, group $\mathrm{D}=5-8$ follicles; group $\mathrm{E}=\leq 4$ follicles. Follicle count is based on the combined total from both ovaries to determine AFC. *Subgroup of oldest patients; poorest prognosis cohort. **1 Ectopic pregnancy. 


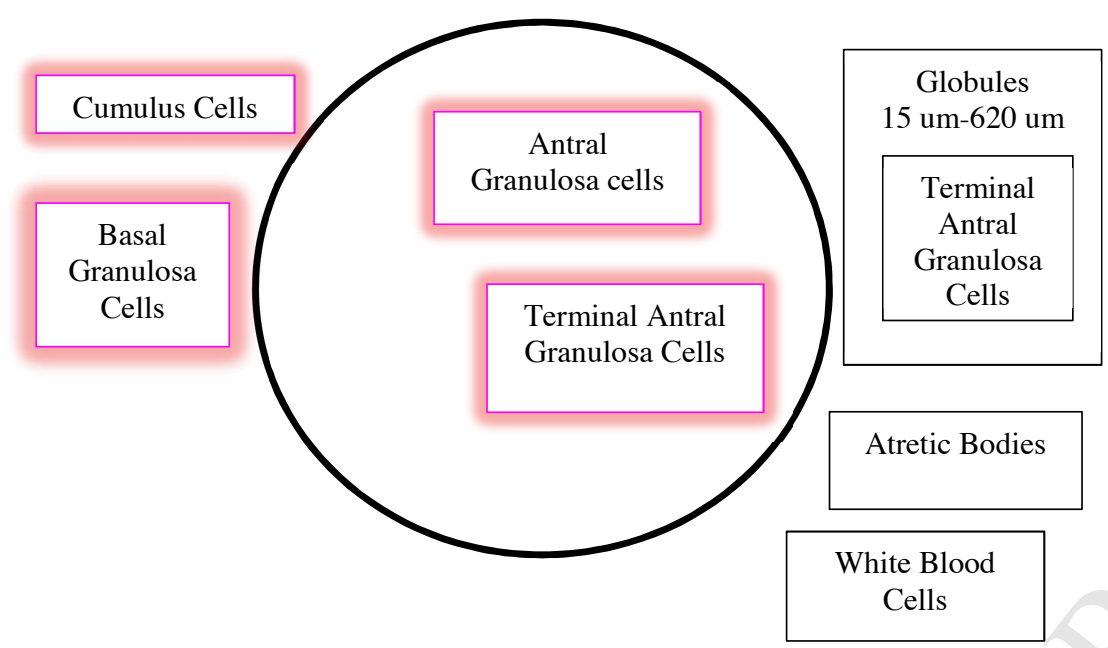

KEY

FSH Receptors 

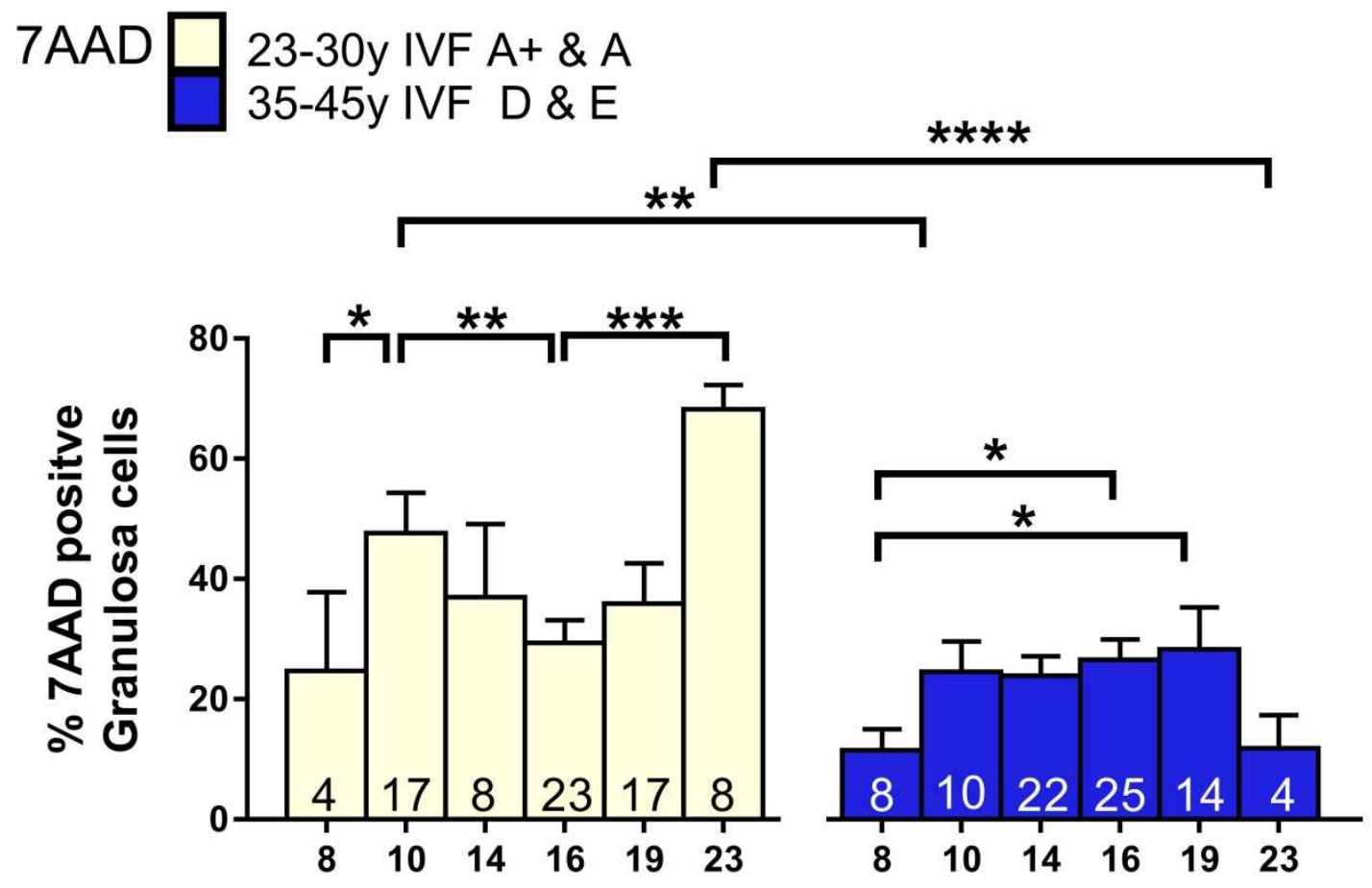

Follicle size $\mathrm{mm}$

OVARIAN
RESERVE GOOD $\mathrm{A}+\mathrm{H}=30-39 \mathrm{~A}=20-29 \mathrm{~B}=13-19 \mathrm{C}=9-12 \mathrm{D}=5-8 \mathrm{E}=\leq 4$ POOR 

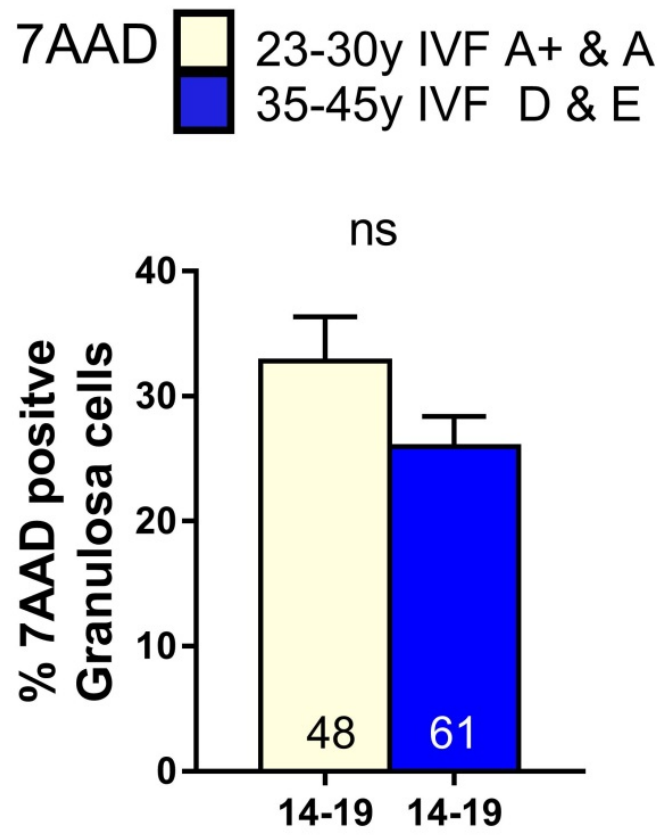

Follicle size $\mathrm{mm}$ 

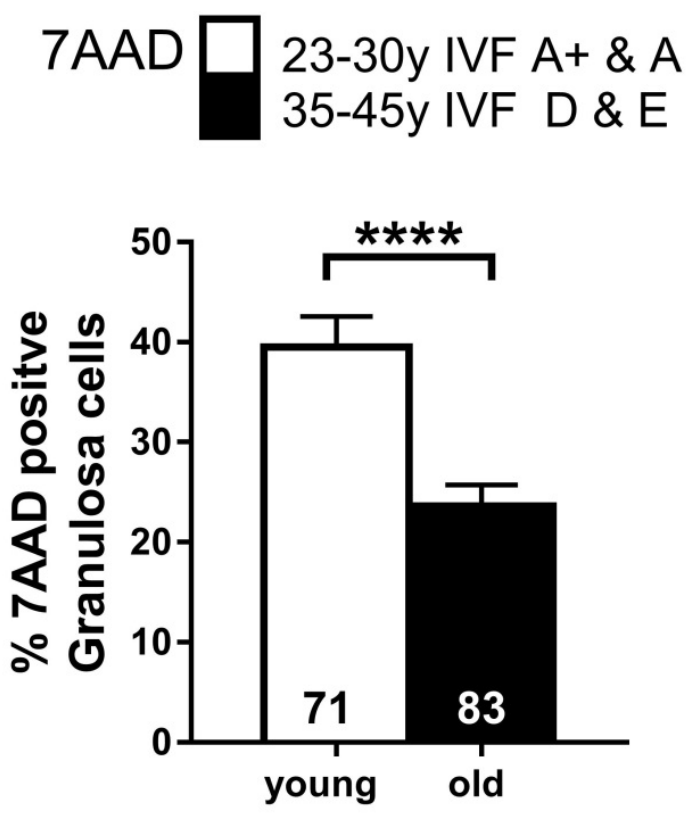

Follicle size pooled 


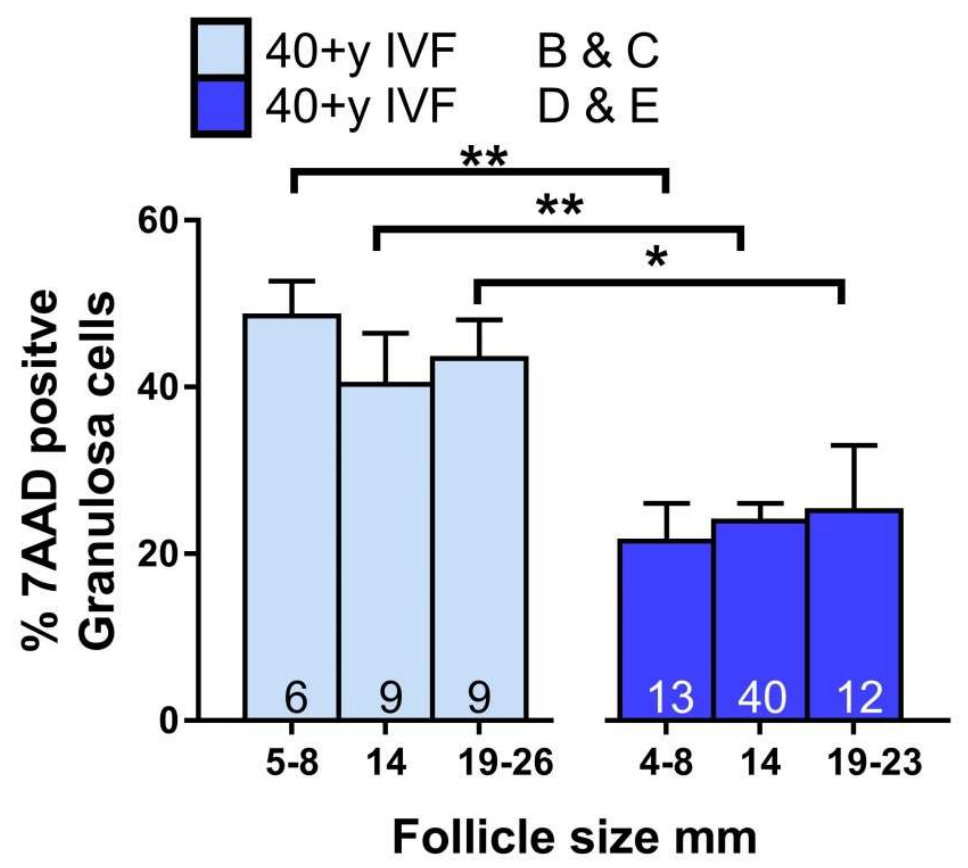

$\begin{aligned} & \text { OVARIAN } \\ & \text { RESERVE }\end{aligned} \mathrm{GOOD} \mathrm{A}+=30-39 \mathrm{~A}=20-29 \mathrm{~B}=13-19 \mathrm{C}=9-12 \mathrm{D}=5-8 \mathrm{E}=\leq 4 \mathrm{POOR}$ 


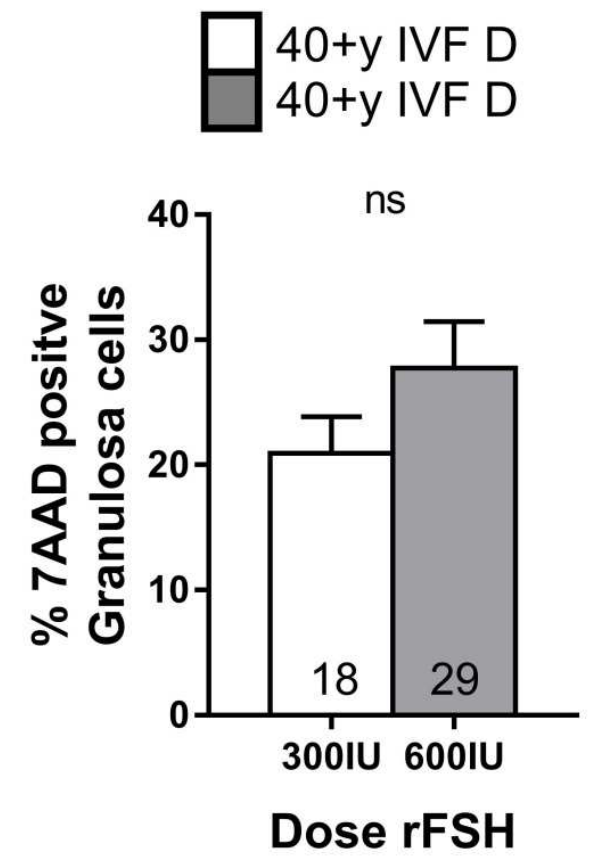




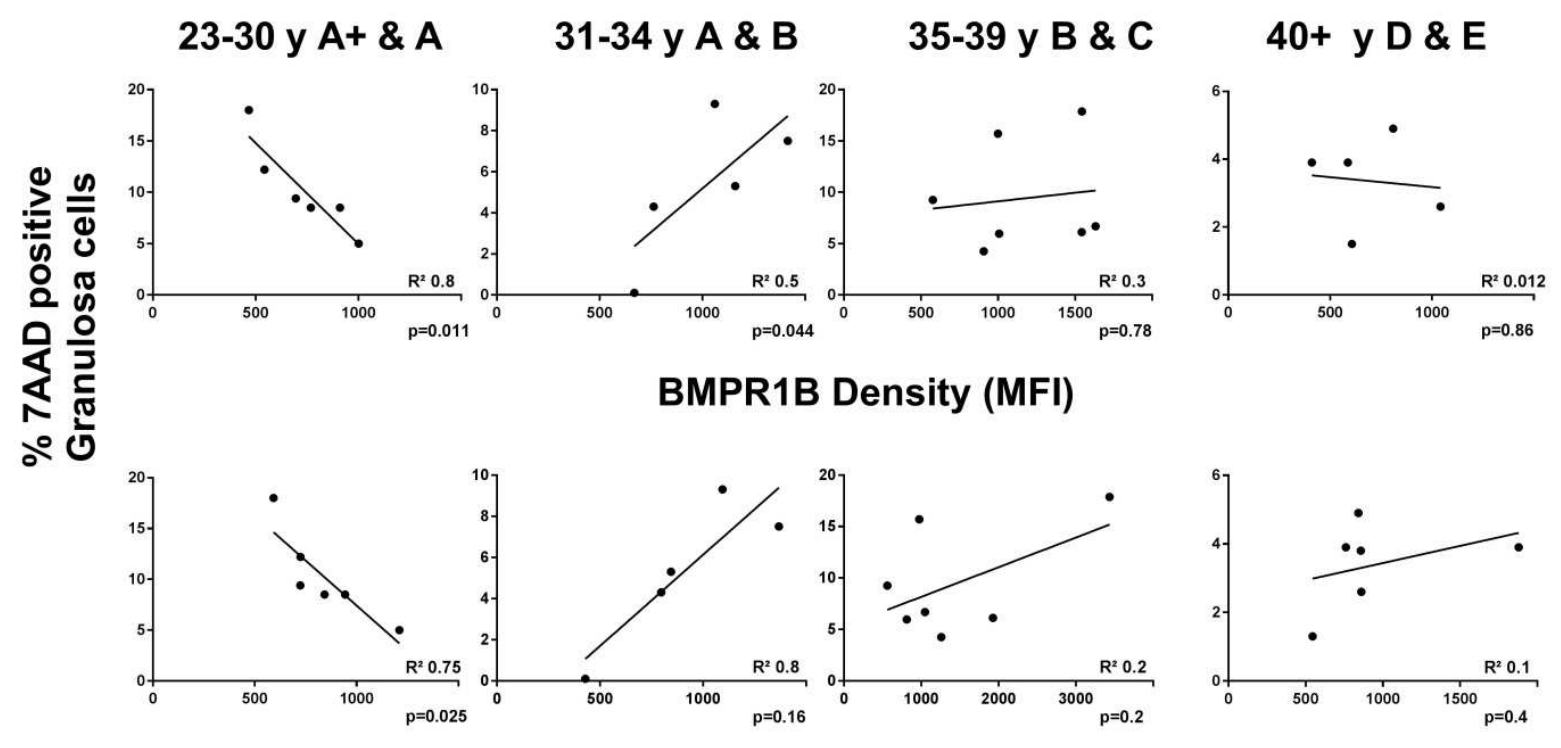

FSHR Density (MFI)

$\begin{aligned} & \text { OVARIAN } \\ & \text { RESERVE }\end{aligned} \mathrm{GOOD} \mathrm{A}+=30-39 \mathrm{~A}=20-29 \mathrm{~B}=13-19 \mathrm{C}=9-12 \mathrm{D}=5-8 \mathrm{E}=\leq 4 \mathrm{POOR}$ 
- Apoptosis was higher in follicles in the young compared to older women

- Preovulatory down-regulation of receptors was associated with reduced apoptosis and fertility

- Apoptosis reflects mitogenic turnover rate of granulosa cells in healthy follicles 